\title{
RADIATION HYGIENIC CONTROL OF MINERAL SUPPLEMENTS AND FEED FOR PIGS
}

\author{
G. Vitorović ${ }^{1}$, B. Mitrović ${ }^{1}$, D. Vitorović ${ }^{2}$, V. Andrić ${ }^{1}$, I. Adamović ${ }^{2}$ \\ ${ }^{1}$ Faculty of Vetenirary Medicine, 11000 Belgrade, Republic of Serbia \\ ${ }^{2}$ Faculty of Agriculture, 11080 Belgrade, Republic of Serbia \\ Corresponding author: Gordana Vitorović, e-mail: radijacija@vet.bg.ac.rs \\ Origial scientific paper
}

\begin{abstract}
Radiometric control of products involved in the food chain is an important part of ongoing quality control of products related to food and feed. Content of primordial and anthropogenic radionuclides in some products directly determines their quality and further methods of usage. The most common way of intake of radionuclides in the human body is ingestion (80 \%) through contaminated food and water. The foods of animal origin are largely represented in the human diet. Therefore radiation control of animal feeds and animal products will contribute to producing food for human nutrition without or with low risk for health. This paper presents the results obtained by gamma spectrometric analysis of mineral additives and mixtures for pig nutrition, from imported and domestic production. In most samples examined, activity levels of natural and radionuclides made during production were in accordance with the regulations. A certain number of tested mineral supplement samples had increased levels of activity of ${ }^{238} \mathrm{U}$ (640$2100 \mathrm{~Bq} / \mathrm{kg}$ ), which was not in accordance with applicable regulations.
\end{abstract}

Key words: animal feed, radioactivity

\section{Introduction}

Broad use of nuclear energy, nuclear weapons, nuclear accidents, the burning of coal, production and processing of phosphate minerals and disposal of radioactive waste, contribute to unequal distribution of radioactivity on the planet. Therefore, it is necessary to pay special attention to systematic radiation hygienic control of feedstuffs of vegetable, mineral and animal origin.

Production of phosphate mineral products from phosphate ore, contributes to over $90 \%$ of the uranium remains in the final products. The world annual processing is about 135 milons tons of phosphate ore, and it is estimated that each year can be expected entry of 21000 tons of uranium in the animal environment which represents about $73 \%$ of the total input (Dangić, 1995). These entries of uranium into the environment can pose significant risks of local population 
exposure to ionizing radiation, so that the level of primary radiation (FON) in the environment of some regions can be increased (IAEA, 1994).

The use of phosphate fertilizers in agriculture is the largest anthropogenic source of uranium in the environment (Stojanović et al., 2006). In processing of phosphate ore mono and dicalcium phosphate are obtained. If used in animal nutrition, as a source of calcium and phosphorus, these compounds may contain high concentration of uranium, even more than $200 \mathrm{ppm}$ (Aruda-Neto et al., 1997). Therefore the use of mono and dicalcium phosphate must be under rigid radiation control of veterinary experts, since otherwise the animals can be contaminated by uranium (Slavata et al., 2002; Izak-Biran et al., 1988; Mitrović et al., 2010).

The environment is particularly threatened by the presence of produced biologically significant radionuclides $\left({ }^{131} \mathrm{I},{ }^{134} \mathrm{Cs},{ }^{137} \mathrm{Cs}\right)$ that arrived to humans and animals after nuclear accidents, which happened (Chernobyl, 1986) due to carelessness of man (Mitrović et al., 2009), or as consequences of natural disaster (Japan 2011). The most important is ${ }^{137} \mathrm{Cs}$ with long half-life (27.7 years), which is capable to deposit in the muscle and milk of animals. Its activity in samples of human food and animal feed was significantly decreased with time. In recent years, the cesium activity in the tested samples was wery low (Pantelic et al., 2007; Slavata et al., 2004; Vitorović et al., 2009) and was in accordance with domestic law regulations (SL 1999).

The aim of the present work was to investigate the specific activity of natural and man made radionuclides in samples of phosphate mineral supplements for pig nutrition, of imported origin and partly from the domestic production (IHP „Prahovo“). These supplements, because of its mode of production and the ore from which they can be removed, may have high levels of natural radioactivity, in particular uranium $\left({ }^{238} \mathrm{U}\right)$. In addition, the research has included variety of final and semi-final mixtures for pig nutrition in order to deterrmine the radiation hygienic safety of these products.

\section{Materials and Methods}

In the samples of phosphate mineral supplements (mono and dicalcium phosphate) and finishing and semi-finishing mixtures for pig nutrition, levels of activity of natural $\left({ }^{40} \mathrm{~K},{ }^{238} \mathrm{U},{ }^{226} \mathrm{R}\right)$ and man made $\left({ }^{137} \mathrm{Cs}\right)$ radionuclides were determined by using gamma spectrometric method. Samples of monocalcium and dicalcium phosphate were collected in 10 local (Serbia) fodder factories and factory IHP „Prahovo“. A number of samples were imported from different countries and were analyzed in the laboratory of radiation Hygiene, Faculty of Veterinary medicine, Belgrade. Gamma spectrometric measurements were performed on an HP Ge detector (ORTEC), resolution $1.73 \mathrm{keV}$, relative efficinency $30.3 \%$. For energy calibration and detector efficinency calibration a radioactive standard „Amersham“ was used. All samples, in the native state, have 
been prepared in marinelly containers and left 40 days to reach equilibrium. Length of gammaspectrometric measurements was $60000 \mathrm{~s}$.

\section{Results and Discussion}

Radioactivity of mono and dicalcium phosphates. Results obtained by gammaspectrometry analysis of monocalcium phosphate samples from animal feed factories from Serbia are shown in Table 1.

Table 1. The level of acivity of ${ }^{40} \mathrm{~K},{ }^{238} \mathrm{U},{ }^{226} \mathrm{Ra}$ and ${ }^{137} \mathrm{Cs}$ in monocalcium phosphate from animal feed factories in Serbia

\begin{tabular}{|l|c|c|c|c|}
\hline \multicolumn{1}{|c|}{ Factory } & $\begin{array}{c}{ }^{40} \mathrm{~K} \\
(\mathrm{~Bq} / \mathrm{kg})\end{array}$ & $\begin{array}{c}{ }^{53} \mathrm{Cs} \\
(\mathrm{Bq} / \mathrm{kg})\end{array}$ & $\begin{array}{c}{ }^{238} \mathrm{U} \\
(\mathrm{Bq} / \mathrm{kg})\end{array}$ & $\begin{array}{c}{ }^{226} \mathrm{Ra} \\
(\mathrm{Bq} / \mathrm{kg})\end{array}$ \\
\hline VZ Subotica & $68 \pm 2$ & $<0.2$ & $60 \pm 4$ & $18 \pm 2$ \\
\hline Belvit Niš & $78 \pm 3$ & $<0.1$ & $79 \pm 3$ & $37 \pm 3$ \\
\hline FSH Jabuka & $78 \pm 3$ & $<0.1$ & $60 \pm 6$ & $33 \pm 3$ \\
\hline Pantelić & $96 \pm 3$ & $<0.2$ & $84 \pm 5$ & $22 \pm 2$ \\
\hline Hrana produkt & $62 \pm 2$ & $<0.1$ & $1 \pm 8$ & $30 \pm 3$ \\
\hline FSH Union & $51 \pm 2$ & $<0.1$ & $12 \pm 0.8$ & $11 \pm 1$ \\
\hline FSH Nutriko & $80 \pm 3$ & $<0.2$ & $72 \pm 4$ & $19 \pm 2$ \\
\hline Narcis - Popović & $50 \pm 2$ & $<0.2$ & $17 \pm 3$ & $6 \pm 2$ \\
\hline VZ Zemun & $78 \pm 3$ & $0.3 \pm 0.1$ & $73 \pm 5$ & $20 \pm 2$ \\
\hline
\end{tabular}

In all monocalcium phosphate samples examined, the level of activity of natural and artificial radionuclides was in accordance with regulations (SL, 1999).

Results obtained by gammaspectrometry analysis of dicalcium phosphate samples from animal feed factories from Serbia are shown in Table 2.

In some samples of dicalcium phosphate, the level of activity of ${ }^{238} \mathrm{U}$ and ${ }^{226} \mathrm{Ra}$ was above the alowed level (VZ Zemun - $1907 \mathrm{~Bq} / \mathrm{kg}$; FSH Union - 860 $\mathrm{Bq} / \mathrm{kg}$ ), and therefore not in accordance with current regulations, as stated by Mitrović et al. (2010).

Table 2. The level of activity of radionuclides in dicalcium phosphate

\begin{tabular}{|l|c|c|c|c|}
\hline \multicolumn{1}{|c|}{ Factory } & $\begin{array}{c}{ }^{40} \mathrm{~K} \\
(\mathrm{~Bq} / \mathrm{kg})\end{array}$ & $\begin{array}{c}{ }^{137} \mathrm{Cs} \\
(\mathrm{Bq} / \mathrm{kg})\end{array}$ & $\begin{array}{c}{ }^{238} \mathrm{U} \\
(\mathrm{Bq} / \mathrm{kg})\end{array}$ & $\begin{array}{c}{ }^{226} \mathrm{Ra} \\
(\mathrm{Bq} / \mathrm{kg})\end{array}$ \\
\hline VZ Zemun & $20 \pm 1$ & $<0.2$ & $1907 \pm 58$ & $400 \pm 21$ \\
\hline FSH Pozega & $80 \pm 3$ & $<0.2$ & $52 \pm 4$ & $17 \pm 2$ \\
\hline FSH Union & $40 \pm 2$ & $<0.1$ & $860 \pm 31$ & $441 \pm 21$ \\
\hline
\end{tabular}

Results obtained by gammaspectrometric analysis of samples of dicalcium phosphate from local factory IHP "Prahovo" are shown in Table 3.

Based on results shown in table 3, two samples (samples 1 and 5) of dicalcium phosphate can be considered as radiation hygienic unsafe, due to higher levels of ${ }^{238} \mathrm{U}$ activity, which is not in accordance with current regulations ( $S L$, 1999). Such samples must not be used in mixtures for animal nutrition. 
In all samples examined, level of ${ }^{137} \mathrm{Cs}$ acivity was low $(0.1-0.4 \mathrm{~Bq} / \mathrm{kg})$.

Table 3. The level of activity of ${ }^{40} \mathrm{~K},{ }^{238} \mathrm{U},{ }^{226} \mathrm{Ra}$ and ${ }^{137} \mathrm{Cs}$ in samples of dicalcium phosphate from factory IHP „Prahovo“

\begin{tabular}{|c|c|c|c|c|}
\hline Sample & $\begin{array}{c}{ }^{40} \mathrm{~K} \\
(\mathrm{~Bq} / \mathrm{kg})\end{array}$ & $\begin{array}{c}{ }^{137} \mathrm{Cs} \\
(\mathrm{Bq} / \mathrm{kg})\end{array}$ & $\begin{array}{c}{ }^{238} \mathrm{U} \\
(\mathrm{Bq} / \mathrm{kg})\end{array}$ & $\begin{array}{c}{ }^{226} \mathrm{Ra} \\
(\mathrm{Bq} / \mathrm{kg})\end{array}$ \\
\hline 1 & $19 \pm 4$ & $<0.4$ & $1800 \pm 114$ & $79 \pm 7$ \\
\hline 2 & $11 \pm 1$ & $<0.3$ & $327 \pm 17$ & $15 \pm 1$ \\
\hline 3 & $34 \pm 1$ & $<0.1$ & $388 \pm 15$ & $183 \pm 9$ \\
\hline 4 & $36 \pm 1$ & $<0.1$ & $242 \pm 12$ & $106 \pm 5$ \\
\hline 5 & $19 \pm 4$ & $<0.4$ & $1789 \pm 114$ & $72 \pm 4$ \\
\hline
\end{tabular}

Results obtained by gammaspetrometric analysis of imported monocalcium phosphate are shown in Table 4.

Table 4. Level of activity of ${ }^{40} \mathrm{~K},{ }^{238} \mathrm{U},{ }^{226} \mathrm{Ra}$ and ${ }^{137} \mathrm{Cs}$ in imported monocalcium phosphate

\begin{tabular}{|l|c|c|c|c|}
\hline $\begin{array}{c}\text { Contry of } \\
\text { origin }\end{array}$ & $\begin{array}{c}{ }^{40} \mathrm{~K} \\
(\mathrm{~Bq} / \mathrm{kg})\end{array}$ & $\begin{array}{c}{ }^{13} \mathrm{Cs} \\
(\mathrm{Bq} / \mathrm{kg})\end{array}$ & $\begin{array}{c}{ }^{238} \mathrm{U} \\
(\mathrm{Bq} / \mathrm{kg})\end{array}$ & $\begin{array}{c}{ }^{226} \mathrm{Ra} \\
(\mathrm{Bq} / \mathrm{kg})\end{array}$ \\
\hline Finland & $42 \pm 9$ & $<0,4$ & $<9$ & $11 \pm 4$ \\
\hline Finland & $41 \pm 5$ & $<0,2$ & $640 \pm 61$ & $<10$ \\
\hline Lithuania & $60 \pm 5$ & $<0,3$ & $44 \pm 8$ & $27+7$ \\
\hline Spain & $22 \pm 3$ & $<0,4$ & $2120 \pm 106$ & $835+44$ \\
\hline
\end{tabular}

In one sample of monocalcium phosphate originating from Finland, the measured activity of ${ }^{238} \mathrm{U}$ was $640 \mathrm{~Bq} / \mathrm{kg}$, and in sample from Spain the level of activity of the same radionuclide was $2120 \mathrm{~Bq} / \mathrm{kg}$ (Table 4). These samples should be considered as hygienic unsafe, since MDK for ${ }^{238} \mathrm{U}$ is up to $500 \mathrm{~Bq} / \mathrm{kg}$. In other samples examined, the level of activity of ${ }^{238} \mathrm{U}$ was in accordance with regulations (SL 1999), these samples are radiation hygienic safe and therefore could be used in animal nutrition. The activity of ${ }^{137} \mathrm{Cs}$ in investigated samples was low $(0.2-0.4$ $\mathrm{Bq} / \mathrm{kg}$ ).

Table 5 shows the results obtained by gammaspetrometric analysis of imported dicalcium phosphate.

Table 5. The level of activity of ${ }^{40} \mathrm{~K},{ }^{238} \mathrm{U},{ }^{226} \mathrm{Ra}$ and ${ }^{137} \mathrm{Cs}$ in imported samples of dicalcium phosphate

\begin{tabular}{|l|c|c|c|c|}
\hline $\begin{array}{c}\text { Contry of } \\
\text { origin }\end{array}$ & $\begin{array}{c}{ }^{40} \mathrm{~K} \\
(\mathrm{~Bq} / \mathrm{kg})\end{array}$ & $\begin{array}{c}{ }^{13 /} \mathrm{Cs} \\
(\mathrm{Bq} / \mathrm{kg})\end{array}$ & $\begin{array}{c}{ }^{238} \mathrm{U} \\
(\mathrm{Bq} / \mathrm{kg})\end{array}$ & $\begin{array}{c}{ }^{226} \mathrm{Ra} \\
(\mathrm{Bq} / \mathrm{kg})\end{array}$ \\
\hline Italy & $29 \pm 1$ & $<0.2$ & $2000 \pm 45$ & $940 \pm 45$ \\
\hline Italy & $35 \pm 2$ & $<0.1$ & $560 \pm 15$ & $293 \pm 14$ \\
\hline Italy & $33 \pm 50$ & $<0.4$ & $640 \pm 61$ & $30 \pm 3$ \\
\hline Unknown & $14 \pm 2$ & $<0.5$ & $1200 \pm 73$ & $58 \pm 4$ \\
\hline Unknown & $17 \pm 3$ & $<0.3$ & $1900 \pm 58$ & $105 \pm 7$ \\
\hline China & $8 \pm 2$ & $<0.2$ & $22 \pm 6$ & $<13$ \\
\hline Lithuania & $60 \pm 5$ & $<0.3$ & $44 \pm 8$ & $27 \pm 7$ \\
\hline Finland & $40 \pm 5$ & $<0.2$ & $45 \pm 4$ & $<13$ \\
\hline
\end{tabular}


Based on results shown in table 5 , it could be observed that samples originating from Italy had high levels of ${ }^{238} \mathrm{U}$ activity $(560-2000 \mathrm{~Bq} / \mathrm{kg})$, as well as two samples of unknown origin (1200 and $1900 \mathrm{~Bq} / \mathrm{kg})$. All these samples can be considered as unsafe (SL 1999). Samples of dicalcium phosphates from China, Lithuania and Finland had low levels of ${ }^{238} \mathrm{U}$ activity $(22-45 \mathrm{~Bq} / \mathrm{kg})$.

Activity of natural radionuclide ${ }^{40} \mathrm{~K}$ in all samples examined was low. The level of activity of artificial radionuclide ${ }^{137} \mathrm{Cs}$ was at the lower limit of detection, which is in accordance with data published by Pantelić et al. (2007).

Radioactivity of feed mixtures for swine nutrition. Table 6 is showing the results of gammaspectrometric measurments of acitivity levels of natural and artificial radionuclides in domestic produced mineral additions, premix and complete feed mixtures used for nutrition of diffrerent swine categories.

Table 6. Level of activity of radionuclides in vitamin premix and complete feed mixtures for pig nutrition, produced in Serbia

\begin{tabular}{|c|c|c|c|c|c|}
\hline $\begin{array}{l}\text { Feed } \\
\text { factory }\end{array}$ & Type of feed & $\begin{array}{c}{ }^{40} \mathrm{~K} \\
(\mathrm{~Bq} / \mathrm{kg})\end{array}$ & $\begin{array}{c}{ }^{137} \mathrm{Cs} \\
(\mathrm{Bq} / \mathrm{kg})\end{array}$ & $\begin{array}{c}{ }^{238} \mathrm{U} \\
(\mathrm{Bg} / \mathrm{kg})\end{array}$ & $\begin{array}{c}{ }^{226} \mathrm{Ra} \\
(\mathrm{Bq} / \mathrm{kg})\end{array}$ \\
\hline \multirow{3}{*}{$\begin{array}{c}\text { VZ } \\
\text { Subotica }\end{array}$} & Premix for pig nutrition & $31 \pm 1$ & $<0.1$ & $5.4 \pm 0.7$ & $3.3 \pm 0.4$ \\
\hline & Complete feed for piglets & $308 \pm 10$ & $<0.1$ & $<2$ & $0.6 \pm 0.1$ \\
\hline & Complete feed for pigs & $221 \pm 7$ & $<0.1$ & $<4$ & $<2$ \\
\hline \multirow{2}{*}{ VZ Zemun } & Vit-mineral premix for piglets & $78 \pm 3$ & $<0.1$ & $507 \pm 16$ & $111 \pm 6$ \\
\hline & Vit-mineral premix for pigs & $223 \pm 7$ & $<0.2$ & $<4$ & $<2$ \\
\hline \multirow{4}{*}{ Belvit Nis } & Vit-mineral premix for piglets & $79 \pm 3$ & $<0.1$ & $10 \pm 1$ & $2.4 \pm 0.4$ \\
\hline & Vit-mineral premix for pigs & $75 \pm 3$ & $<0.1$ & $7 \pm 1$ & $2.4 \pm 0.5$ \\
\hline & Complete feed for piglets & $267 \pm 8$ & $<0.1$ & $<2$ & $1.6 \pm 0.3$ \\
\hline & Complete feed for growing pigs & $208 \pm 7$ & $<0.1$ & $4.7 \pm 1.6$ & $0.8 \pm 0.2$ \\
\hline \multirow{2}{*}{$\begin{array}{c}\text { FSH } \\
\text { Jabuka }\end{array}$} & Complete feed for piglets & $242 \pm 8$ & $<0.1$ & $<2.9$ & $1.4 \pm 0.4$ \\
\hline & Complete feed for growing pigs & $183 \pm 6$ & $<0.1$ & $5.8 \pm 0.9$ & $<3$ \\
\hline \multirow{3}{*}{ Pantelic } & Complete feed for piglets & $291 \pm 9$ & $<0.2$ & $3.9 \pm 0.4$ & $<2$ \\
\hline & Complete feed for pigs & $279 \pm 9$ & $<0.2$ & $<4$ & $<2$ \\
\hline & Complete feed for growing pigs & $229 \pm 7$ & $<0.2$ & $<3$ & $<2$ \\
\hline \multirow{4}{*}{$\begin{array}{c}\text { Hrana } \\
\text { produkt }\end{array}$} & Premix for piglets & $73 \pm 3$ & $<0.1$ & $<11$ & $1.2 \pm 0.2$ \\
\hline & Premix for pigs & $76 \pm 3$ & $<0.1$ & $25 \pm 6$ & $12 \pm 1$ \\
\hline & Complete feed for piglets & $280 \pm 9$ & $<0.1$ & $<14$ & $<2.6$ \\
\hline & Complete feed for pigs & $230 \pm 7$ & $<0.1$ & $<14$ & $2.9 \pm 0.6$ \\
\hline \multirow{4}{*}{ FSH Union } & Vit-mineral premix for growing pigs & $25 \pm 1$ & $<0.1$ & $9.6 \pm 2.7$ & $4.2 \pm 0.5$ \\
\hline & Complete feed for piglets & $215 \pm 7$ & $<0.1$ & $<1$ & $<2$ \\
\hline & Complete feed for sows & $258 \pm 8$ & $<0.1$ & $12.8 \pm 1.6$ & $6 \pm 1$ \\
\hline & Complete feed for growing pigs & $221 \pm 7$ & $<0.1$ & $<1.6$ & $<1.9$ \\
\hline \multirow{2}{*}{$\begin{array}{c}\text { FSH } \\
\text { Nutriko }\end{array}$} & Complete feed for piglets & $78 \pm 3$ & $0.7 \pm 0.1$ & $5 \pm 1$ & $<2$ \\
\hline & Complete feed for pigs & $252 \pm 8$ & $<0.1$ & $<3$ & $<1.3$ \\
\hline \multirow{4}{*}{$\begin{array}{l}\text { Narcis } \\
\text { Popovic }\end{array}$} & Vit-mineral premix for pigs & $511 \pm 16$ & $<0.5$ & $<7$ & $<4$ \\
\hline & Complete feed for piglets & $340 \pm 11$ & $<0.2$ & $<4$ & $<2$ \\
\hline & Complete feed for pigs & $278 \pm 9$ & $<0.2$ & $<3$ & $<2$ \\
\hline & Premix for growing pigs & $220 \pm 7$ & $<0.2$ & $<4$ & $<2$ \\
\hline \multirow{2}{*}{$\begin{array}{c}\text { FSH } \\
\text { Pozega }\end{array}$} & Complete feed for piglets & $338 \pm 11$ & $<0.2$ & $4.1 \pm 0.8$ & $<1.5$ \\
\hline & Complete feed for pigs & $196 \pm 6$ & $<0.2$ & $<2.3$ & $<1.4$ \\
\hline
\end{tabular}


In all samples examined, the level of ${ }^{137} \mathrm{Cs}$ activity was on the lower limit for detection. Considering natural radionuclides, the highest activity was measured for ${ }^{40} \mathrm{~K}$. The activity of this radionuclide was almost the same in all samples of mixtures, which originating from different animal feed factories. Other natural radionuclides were present, but with low activity levels. Only in the sample of vitamin-mineral premix for piglets from animal feed factory "VZ Zemun", a higher activity of ${ }^{238} \mathrm{U}$ was determined $(507 \mathrm{~Bq} / \mathrm{kg})$. This might be due to usage of dicalcium phosphate or any other phosphate mineral addition with increased activity of this particular radionuclide.

The results of measurements of activity of natural and artificial radionuclides in imported mixtures for pig nutrition are shown in Table 7.

Table7. The level of radionuclides activity in imported vitamin premix and complete feed mixtures for pig nutrition

\begin{tabular}{|c|l|c|c|c|c|c|}
\hline Sample & \multicolumn{1}{|c|}{ Type of feed } & $\begin{array}{c}\text { Country of } \\
\text { origin }\end{array}$ & $\begin{array}{c}{ }^{40} \mathrm{~K} \\
(\mathrm{~Bq} / \mathrm{kg})\end{array}$ & $\begin{array}{c}{ }^{137} \mathrm{Cs} \\
(\mathrm{Bq} / \mathrm{kg})\end{array}$ & $\begin{array}{c}{ }^{238} \mathrm{U} \\
(\mathrm{Bq} / \mathrm{kg})\end{array}$ & $\begin{array}{c}{ }^{226} \mathrm{Ra} \\
(\mathrm{Bq} / \mathrm{kg})\end{array}$ \\
\hline 1 & $\begin{array}{l}\text { Mineral-vitamin } \\
\text { premix }\end{array}$ & Denmark & $44 \pm 4$ & $<0.4$ & $597 \pm 18$ & $248 \pm 16$ \\
\hline 2 & $\begin{array}{l}\text { Mineral-vitamin } \\
\text { premix }\end{array}$ & Germany & $29 \pm 3$ & $<0.3$ & $718 \pm 20$ & $326 \pm 17$ \\
\hline 3 & $\begin{array}{l}\text { Mineral-vitamin } \\
\text { premix }\end{array}$ & Germany & $17 \pm 3$ & $<0.3$ & $181 \pm 31$ & $86 \pm 8$ \\
\hline 4 & $\begin{array}{l}\text { Vit-mineral premix } \\
\text { for growing pigs }\end{array}$ & Germany & $61 \pm 6$ & $<0.5$ & $410 \pm 30$ & $167 \pm 13$ \\
\hline 5 & Premix for pigs & France & $62 \pm 4$ & $<0.3$ & $<9$ & $<10$ \\
\hline
\end{tabular}

Examinations showed that ${ }^{137} \mathrm{Cs}$ activity was on the low detection levels, and the highest level of activity was determined for ${ }^{40} \mathrm{~K}$. The activity of this radionuclide was similar in all samples investigated. In two samples of mineralvitamin premix for pigs, a higher activity levels of ${ }^{238} \mathrm{U}$ and ${ }^{226} \mathrm{Ra}$ than allowed by regulations were determined.

\section{Conclusion}

Based on obtained results of gammaspectrometric analysis of mono and dicalcium phosphates in this investigation, it can be concluded that systematic radiation hygienic control of mineral additions is needed, either if these products are imported, or produced in Serbia but from imported ore. Activity of these mineral additions might increase the radioactivity of final feeds in animal nutrition. If the radiation control would not be established as an obligatory procedure, it might be expected that Uranium would eventually be included into food chain, which would lead to serious health problems both in humans and animals

The results of investigation showed that different types of mixtures for swine nutrition produced in Serbian animal feed factories are radiation hygienic 
safe. In importing of different mixtures for pig nutrition, a radiation hygienic control should be an obligatory procedure.

\title{
Acknowledgment
}

Research was financed by the Ministry of Education and Science, Republic of Serbia, projects TR 31003, TR 34013, TR 31081, III 45012.

\section{Radijaciono higijenska kontrola mineralnih dodataka i smeša za ishranu svinja}

\author{
G. Vitorović, B. Mitrović, D. Vitorović, V. Andrić, I. Adamović
}

\section{Rezime}

Radiometrijska kontrola proizvoda uključenih u lanac ishrane je važan segment stalne provere kvaliteta proizvoda vezanih za ishranu ljudi i životinja. Sadržaj primordijalnih i antropogenih radionuklida u nekim proizvodima direktno određuje njegov kvalitet i dalji način upotrebe. Najčešći put unošenja radionuklida u ljudski organizam je ingestija $(80 \%)$, putem kontaminirane hrane i vode. Kako su namirnice životinjskog porekla zastupljene u velikoj količini u ishrani ljudi, kontrola hrane za životinje i proizvoda animalnog porekla omogućila bi ishranu ljudima bez rizika. U radu su prikazani rezultati dobijeni gamaspektrometrijskom analizom mineralnih dodataka, pred smeša i gotovih smeša za ishranu svinja iz uvoza i domaće proizvodnje. U većini ispitivanih uzoraka nivo aktivnosti prirodnih i proizvedenih radionuklida je bio u skladu sa propisima. Jedan broj ispitanih uzoraka mineralnih dodataka iz uvoza i domaće proizvodnje imao je povećan nivo aktivnost ${ }^{238} \mathrm{U}(640-2100 \mathrm{~Bq} / \mathrm{kg})$, što nije u skladu sa važećim propisima.

\section{References}

ARUDA-NETO J.D.T., MANSO GUEVARA M.V., NOGUEIRA G.P., SAIKI M., CESTARI, A.C., SHTEJER K. (2004): Long term accumulation of uranium in bones of Wistar rats as a function of intake dosages. Radioactive Protection Dosimetry, 112, 3, 385-393.

ARRUDA-NETO J.D.T, TAVARES M.V., FILADELFO M. (1997): Concentration of uranium in animal feed supplements: measurments and dose estimates. Journal of Radioanalytical and Nuclear Chemistry, 221, 97-104.

DANGIĆ A., (1995): Geohemijski procesi u prirodi i radionuklidi. jonizujuća zračenja u prirodi (monografija). JDZZ, Beograd, 41-56.

IAEA (1994): Handbook of parameter values for the predicition of radionuclide transfer in temperate environmenta. Techical Reports Series, No.364, Vienna. 
IZAK-BIRAN T., SCHLESINGER T., WEINGARTEN R., EVEN O., SHAMAI Z., ISRAELI M., (1988): Concentrations of U and Po in animal feed supplements, in poultry meat and eggs. Health Physics, 56, 315-319.

MITROVIĆ B., VITOROVIĆ G., VITOROVIĆ D., PANTELIĆ G., ADAMOVIĆ I. (2009): Natural and anthropogenic radioactivity in the environment of mountain region of Serbia. Journal of Environmental Monitoring, 11, 2, 383-388.

MITROVIĆ B., VITOROVIĆ G., ANDRIĆ V., VITOROVIĆ D. (2010): Ispitivanje radioaktivnosti u fosfatnim mineralnim dodacima za ishranu životinja iz uvoza i domaće proizvodnje, na teritoriji republike Srbije. 21. Svetovanje veterinara Srbije, 58-64.

PANTELIĆ G., JAVORINA LJ., VITOROVIĆ G., VULETIĆ V., TANASKOVIĆ I., EREMIĆ-SAVKOVIĆ M. (2007): Two descades of ${ }^{137} \mathrm{Cs}$ activity measurements in cattle feed and milk in Serbia. IRPA, Regional Congress for Central and Eastern Europe - Regional and Global Aspects of radiation protection, 24-28 September, Brasov, Romania. (CD).

SL (1999): Službeni List SRJ, 99.

SLAVATA B., VITOROVIĆ G., DŽONIĆ S. (2002): Radijaciono-higijenska kontrola uvoznih namirnica i stočnih hraniva. Vet. Glasnik, 56, 3-4, 237-244.

SLAVATA B., VITOROVIĆ G., PANTELIĆ G. (2004): Radijaciono higijenska kontrola hrane za životinje i sirovina za proizvodnju hrane za životinje. Veterinarski glasnik, 58, (vanredni 3-4), 211-217.

STOJANOVIĆ M., KOVAČEVIĆ D., BALTIĆ M., MITROVIĆ A. (2006): Fosforgips - izvor radionuklida - mogućnost njihovog uklanjanja. Monografija, ITNMS, 117-140.

VITOROVIĆ G., GRDOVIĆ S., MITROVIĆ B., OBRADOVIĆ M., PETRUJKIĆ B. (2009): Radioecological investigation of food of animal origin in Belgrade environment. Japanese Journal of Veterinary Research, 57, 3, 169-173. 